\title{
Evaluation of antifungal potential of Ruta chalepensis L. essential oil against Mauginiella scaettae, fungus responsible for the inflorescence rot of date palm (Phoenix dactylifera $\mathbf{L}$. )
}

\author{
Hadjra Hammia and Yamina Bouatrous* \\ Department of Natural Sciences and Life, Faculty of Exact Sciences and Natural Sciences and Life, Mohamed Khider University, Biskra, \\ BP145, 07000-Algeria. \\ * Laboratory of Genetics, Biotechnology and Valorization of Bio-Resource (GBVB), Department of Natural Sciences and Life, Faculty of Exact \\ Sciences and Natural Sciences and Life, Mohamed Khider University, Biskra, BP145,07000-Algeria
}

\section{Article Info}

Article history

Received 1 November 2021

Revised 25 December 2021

Accepted 26 December 2021

Published Online 30 December 2021

\section{Keywords}

Mauginiella scaettae

Antifungal activity

Ruta chalepensis

GC-MS analysis

\begin{abstract}
The objective of our work is to research for new natural bioactive products as an alternative means of control against the fungus responsible for the inflorescence rot of date palm Mauginiella scaettae. In vitro tests of the antifungal activity of essential oil of Ruta schalepensis were performed. The results showed that the yield of essential oil obtained by hydrodistillation of the aerial part of $R$. chalepensis was $0.41 \pm$ $0.02 \%$. Their chemical composition was analyzed by GC and GC/MS technique. 09 chemical compounds were identified, representing $99.99 \%$ of the total composition of the essential oil. The main constituents were camphor $(76.57 \%)$, followed by borneol $(8.75 \%)$, eucalyptol (3.12\%), trans-4-Isopropyl-1-methyl2-cyclohexen-1-ol (3.55\%) and 1-Terpineol (2.34\%). Three concentrations $(0.25,0.5$ and 1$) \mu 1 / \mathrm{ml}$ PDA (potato dextrose agar) of the essential oil were used to study in vitro antifungal activity against $M$. scaettae. The results showed a significant effect on mycelial growth. The values of the inhibition rate vary between $47.88 \pm 1.78 \%$ and $83.49 \pm 1.78 \%$. In comparison between these three concentrations of essential oil, the two concentrations 0.5 and $1 \mu \mathrm{l} / \mathrm{ml}$ PDA have important antifungal capacity than the third concentration $0.25 \mu \mathrm{l} / \mathrm{ml}$ PDA. Our results indicated that the essential oil of $R$. chalepensis could be used as a biofungicide for fungal diseases of date palm.
\end{abstract}

\section{Introduction}

The date palm (Phoenix dactylifera L.) commonly called as date palm is a plant of great socio-economic interest. It is a foremost cultivated crop in the Middle East, Arabian and North African countries (Imad Uddin et al., 2020). In Algeria, the phoeniculture occupies a place of first rank in the Saharan agriculture (Benziouche and Cheriet, 2012). However, this culture meets immense difficulties in particular the pests, diseases and weeds. These pests and diseases cause considerable losses to production and can lead to genetic erosion (Dakhia et al., 2013). Among the diseases that infect date palms is inflorescence rot. This is a serious disease that can be epidemic in the wettest growing regions or in very wet years (Carpenter and Elmer, 1978). In North Africa, this disease (called Khamedj by the natives) has been reported in almost all date palm growing areas (Abdullah et al., 2005). The economic importance of this disease is attributed to considerable yield losses (Bounaga and Djerbi, 1990). The fungus, M. scaettae is considered the main cause of inflorescence rot. The causal fungus of this disease was reported for the first time by Cavara in Libya in 1925 (Abdullah et al., 2005). It is an imperfect fungus of the order Hyphales, with chains

\footnotetext{
Corresponding author: Ms. Hadjra Hammia

Department of Natural Sciences and Life, Faculty of Exact Sciences and Natural Sciences and Life, Mohamed Khider University, Biskra, BP145, 07000-Algeria

E-mail: hadjra.hammia@univ-biskra.dz

Tel.: +213661569660
}

Copyright () 2021 Ukaaz Publications. All rights reserved.

Email: ukaaz@yahoo.com; Website: www.ukaazpublications.com of hyaline conidia, fragmented into single or two-celled articles (Abdullah et al., 2005; Bounaga and Djerbi, 1990). In order to control this disease, various means of control have been adopted, including the removal of contaminated parts of the inflorescence and burning them immediately after harvest and the treatment of palms with various fungicides (Carpenter and Elmer, 1978; Chabrolin, 1930). The use of these fungicides can have harmful consequences on humans and their environment, due to toxicological and eco-toxicological risks. In this context, there is a major interest in natural extracts of medicinal plants such as essential oils as a means of biological control, given their antimicrobial activity which is linked to their chemical composition and in particular to the nature of their major volatile components (Bouatrous, 2019; Bouhlali et al., 2021; Caillet and Lacroix, 2007). Recently, many studies have focused on the biological and antifungal properties of herbal medicines (Parveen et al., 2020). Among the biological and antifungal properties studied cited the oils of essential oils and extracts of Rutaceae which are sources of various natural products with biological activities, including antifungal, antioxidant, depressant and anti-inflammatory (Merghache et al., 2009; Mejri et al., 2013; Aouadhi et al., 2013). Among the species belonging to the Rutaceae family, Ruta chalepensis L. commonly called Fidjel in Algeria. It is a spontaneous species, very abundant, it grows spontaneously in rock gardens, lawns, rocks and dry hills (Beniston, 1984); characterized by oval, large, pinnate and blue-green leaves which have numerous lanceolate oblong lobes. The inflorescence of this species is in the form of a cyme (Daoudi et al., 2016). 
The main objectives of this study were: (i) to determine the chemical composition of the essential oil of $R$. chalepensis and (ii) to investigate in vitro the antifungal activity of this oil against the mycelial growth of $M$. scaettae.

\section{Materials and Methods}

\subsection{Plant material}

The plant of $R$. chalepensis was collected in March 2019, in the commune of M'chounech (Wilaya of Biskra). It was identified in the Centre of Scientific and Technical Research on Arid Regions (CRSTRA) at the University of Biskra. The aerial part (stems and leaves) of the specie $R$. chalepensis was air-dried, away from light and then stored in clean paper bags until the time of extraction.

\subsection{Essential oil extraction}

The essential oil of $R$. chalepensis was extracted by hydrodistillation in a Clevenger-type. $100 \mathrm{~g}$ of dry plant material placed in a Pyrex glass flask, and extracted with $1000 \mathrm{ml}$ of distilled water for 3 hours. The essential oil was collected and stored at $4{ }^{\circ} \mathrm{C}$ away from light (Ismaily Alaoui et al., 2014).

\subsubsection{Calculation of essential oil yield}

The yield of essential oil was defined according to the Afnor standard (1986). It is expressed as a percentage and calculated by the following formula:

$$
\mathrm{Rd}=\mathrm{M}^{\prime} / \mathrm{M} .100
$$

Rd: The yield of essential oil (\%)

M': the quantity of oil obtained (g)

M: the mass of dry plant material (g) (Afnor, 1986).

\subsection{Gas chromatography-mass spectrometry (GC-MS) analysis}

The analysis was carried out in a Trace 1310 gas chromatograph equipped with an ISQ single quadrupole mass spectrometer (Thermo Fisher Scientific, Austin, TX). The procedure was set to an initial temperament $60^{\circ} \mathrm{C}$ for $6 / \mathrm{min}$, then ramp at $2^{\circ} \mathrm{C} / \mathrm{min}$ to $230^{\circ} \mathrm{C}$, and finally $30 / \mathrm{min}$ in $230^{\circ} \mathrm{C}$. The ion source and detector temperature was $250^{\circ} \mathrm{C}$ and $250^{\circ} \mathrm{C}$, respectively. Sample filtered with a $0.22 / \mu \mathrm{m}$ disposable syringe filter. A volume of $1 / \mu 1$ was injected in split less model. Separation of sample was performed on a Thermo TG-WAXMS GC column $(60 / \mathrm{m} \times 0.25 / \mathrm{mm}$ ID $\times 0.25 /$ $\mu \mathrm{m}$ ) using helium as carrier gas at $1.2 / \mathrm{ml} / \mathrm{min}$. Mass spectral scan range was set at the rate of 55-550 (amu). Peak identification was conducted by comparison of the known components stored in the NIST Demo, Wiley7, Wiley9, redlip, mainlip, WinRI (Adams, 2001).

\subsection{Fungal material}

\subsubsection{Isolation and purification of the pathogen}

Small pieces ( $2 \mathrm{~cm}$ long) from infected inflorescence examined were surface-sterilized with $2 \%$ sodium hypochlorite for $3 \mathrm{~min}$, rinsed three times for $3 \mathrm{~min}$ in sterile distilled water and blotted dry on sterilized filter paper. After these, fragments were dried on sterile pads and then placed on top of moist sterilized filter paper in Petri dishes, with 3 fragments per dish. Incubation took place at $25 \pm$ $2^{\circ} \mathrm{C}$ for 7 days in the dark. Once well differentiated colonies, they will be then re-inoculated several times in new Petri dishes containing PDA medium for obtaining purified cultures. After purification, macro and microscopic observations were performed for identification of the fungi based on the morphological characteristics of the mycelium, and conidia (Rattan and Al-Dboon, 1980; Abdullah et al., 2005).

\subsection{Antifungal activity of $R$. chalepensis essential oil}

The evaluation of the antifungal activity of essential oil is performed by the direct contact method. Essential oil was diluted with Tween $20(0.1 \% \mathrm{v} / \mathrm{v})$ and then added into $20 \mathrm{ml}$ PDA to obtain different final concentrations. Concentrations of $0.25,0.5$ and $1 \mu \mathrm{l} / \mathrm{ml}$ PDA were prepared. $1 \mathrm{ml}$ of each concentration is added to each Petri dish containing $20 \mathrm{ml}$ of PDA medium, and then stirred for $5 \mathrm{~min}$ in order to homogenize the medium PDA with essential oil. After solidification of the medium, A mycelial disk of $0.5 \mathrm{~cm}$ in diameter, cut from the periphery of a 7-day old culture, was inoculated in the centre of each PDA plate ( $9 \mathrm{~cm}$ diameter), and then incubated in the dark at $25 \pm 2{ }^{\circ} \mathrm{C}$ for 7 days. $20 \mathrm{ml}$ PDA containing Tween $20(0.1 \%)$ without essential oil was used as negative control. Three replicates were used for tested oil and control (Remmal et al., 1993). A daily measurement of the radial growth diameter of each cultured explants was taken, by measuring the average of two perpendicular diameters passing through the centre of each dish. The inhibition rate and mycelial growth rate of each concentration is determined by the following formulas:

\section{- Inhibition rate (IR)}

$\mathrm{IR}=[(\mathrm{L}-1) / \mathrm{L}] \times 100$

IR: Inhibition rate of mycelial growth (\%);

L: Diameter of the control colony $(\mathrm{cm})$;

1: Diameter of the colony in the experiment $(\mathrm{cm})$; (Leroux and Credet, 1978).

\section{- Mycelial growth rate (MGR)}

$$
\begin{aligned}
\text { MGR }= & {\left[D_{1} / T_{1}\right]+\left[\left(D_{2}-D_{1}\right) / T_{2}\right]+\left[\left(D_{3}-D_{2}\right) / T_{3}\right] } \\
& +\ldots+\left[\left(D_{n}-D_{n-1}\right) / T_{n}\right] \\
\text { MGR = } & \text { Speed of mycelial growth (cm/day) } \\
\mathrm{D}= & \text { Diameter of the growth zone on each day }(\mathrm{cm}) . \\
\mathrm{T}= & \text { Incubation time (Day); (Cahagnier and Richard- } \\
& \text { Molard, 1998). }
\end{aligned}
$$

\subsection{Minimum inhibitory concentrations (MIC)}

Minimum inhibitory concentration (MIC) of essential oil was determined according to the method reported by (Remmal et al., 1993). It corresponds to the minimum concentration of essential oil for which no growth observed by naked eyes. Its determination was made by observing the total absence of the growth of the strains in the different concentrations of essential oil tested.

\subsection{Statistical analysis}

The results obtained were subjected to one-way analysis of variance (ANOVA), followed by Newman-Keuls test, and the means are represented as (mean $\pm \mathrm{SD}$ ). The results are significant when $p<0.05$, using the XLSTAT 2014.5.03 analysis software. 


\section{Results}

3.1 Essential oil yield and chemical composition of R. chalepensis

The yield of essential oil obtained by hydrodistillation of $R$. chalepensis was $0.41 \pm 0.02 \%$. This oil had a dark yellow color, and a strong fetid odor.

The gas chromatography-mass spectrometry (GC-MS) analysis of extracted essential oil of $R$. chalepensis revealed 09 compounds representing $99.99 \%$ of the total chemical composition. The essential oil was characterized by high content of oxygenated monoterpens (97.38\%) among which, camphor (76.57\%), borneol (8.75\%), eucalyptol (3.12\%), trans-4-Isopropyl-1-methyl-2cyclohexen-1-ol $(3.55 \%)$ and 1-Terpineol $(2.34 \%)$ were the most abundant. Else, the essential oil exhibited low amounts of monoterpens, dl-Limonene (1.56\%), and p-Cymene $(1.05 \%)$. The results of the GC-MS analysis are summarized in Table 1 and Figure 1.

Table 1: Chemical composition of the essential oil of $R$. chalepensis

\begin{tabular}{|c|l|c|c|}
\hline No & Compound Name & RT & Area \% \\
\hline 1 & dl-Limonene & 15.28 & 1.56 \\
2 & Eucalyptol & 15.72 & 3.12 \\
3 & p-Cymene & 19.37 & 1.05 \\
4 & Acetic acid, 2-ethylhexyl ester & 31.95 & 1.35 \\
5 & Camphor & 34.23 & 76.57 \\
6 & trans- 4-Isopropyl-1-methyl- & 37.13 & 3.55 \\
& 2-cyclohexen-1-ol & 39.49 & 1.70 \\
7 & 3-Cyclohexen-1-ol,4-methyl- & & \\
& 1-(1-methylethyl) & 40.99 & 2.34 \\
9 & 1-terpineol (Terpenene-1-ol) & 45.17 & 8.75 \\
& Borneol & & 99.99 \\
\hline
\end{tabular}

RT: retention time.

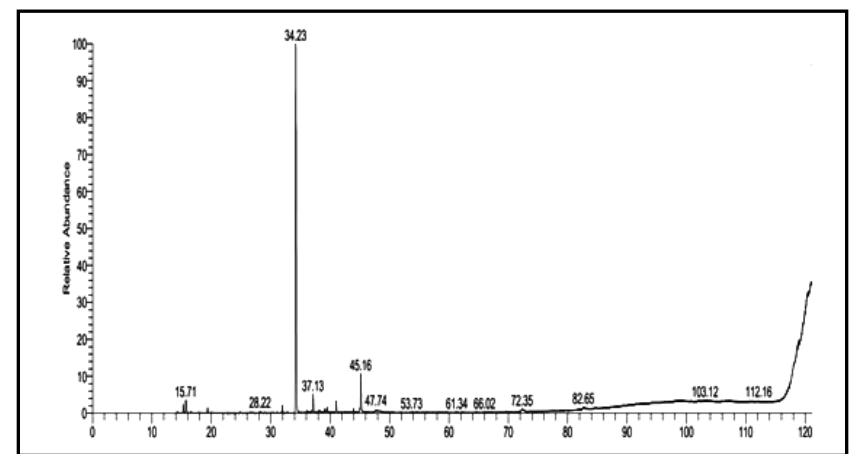

Figure 1: Chromatographic profile for GC-MS analysis of R. chalepensis essential oil.

\subsection{Antifungal activity of essential oil}

\subsubsection{Inhibition rate}

The essential oil of $R$. chalepensis was tested for antifungal activity against plant pathogenic fungi, $M$. scaettae. Our results showed that the inhibition rate is highly significant $(p \leq 0.001)$ for different concentrations. The concentrations of essential oil ( 0.5 and 1) $\mu 1 /$ $\mathrm{ml}$ PDA showed significant inhibition rate values respectively 78.12 $\pm 11.08 \%$ and $83.48 \pm 1.78 \%$, compared to the third concentration $0.25 \mu \mathrm{l} / \mathrm{ml}$ PDA $47.88 \pm 1.78 \%$ (Figure 2).

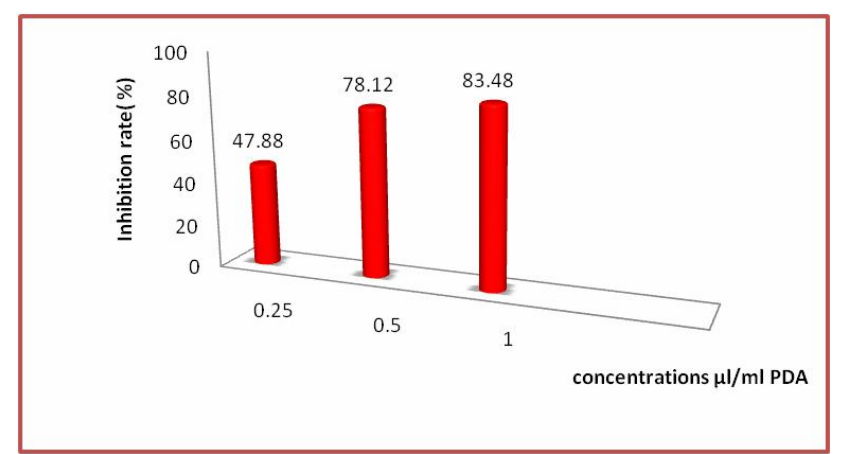

Figure 2:Inhibition rate of mycelial growth of the fungal strain tested by essential oil of $R$. chalepensis.

\subsubsection{Mycelial growth rate (MGR)}

The results of the antifungal assay of the essential oil extract of $R$. chalepensis showed that there is a very highly significant difference $(p<0.0001)$. The concentrations of essential oil $(0.25$, 0.5 and $1 \mu \mathrm{l} / \mathrm{ml}$ PDA) lowered the fungal growth of $M$. scaettae. The lowest growth rate was observed at 0.5 and $1 \mu 1 / \mathrm{ml}$ PDA concentrations where $0.54 \pm 0.08$ and $0.51 \pm 0.01 \mathrm{~cm} /$ day are recorded, respectively. Results of the separation of the growth rate mean show that no difference was observed between the two concentrations ( 0.5 and $1 \mu \mathrm{l} / \mathrm{ml}$ PDA). On the other hand, the highest growth rate was observed in the control $(1.14 \pm 0.15 \mathrm{~cm} /$ day $)$ compared to the tested doses (Figure 3).

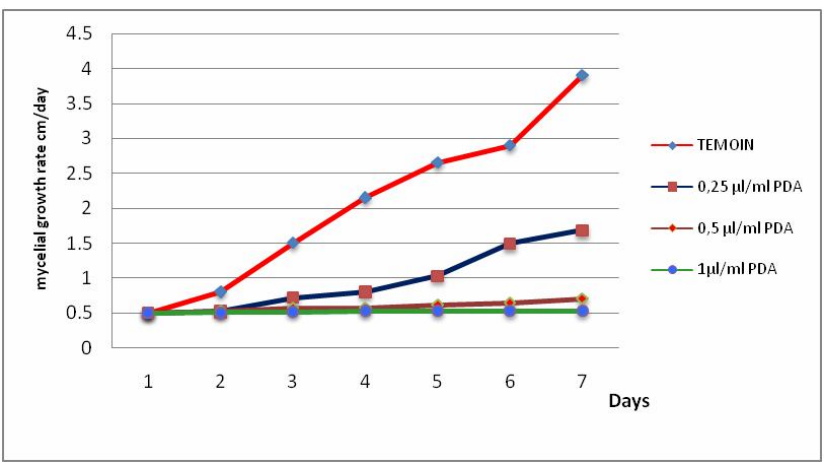

Figure 3: Evolution of the mycelial growth of M. scaettae according to the different concentrations of the essential oil of $R$. chalepensis during seven days of incubation.

3.3 Minimum inhibitory concentrations (MIC)

According to the results recorded in Figure 2 which presents the inhibition rate of mycelial growth of the fungal strain tested by essential oil of $R$. chalepensis. It has been shown that all the concentrations of essential oil applied $(0.25,0.5$ and 1$) \mu 1 / \mathrm{ml}$ PDA partially inhibited the growth of the fungal strains tested where we recorded $47.88 \pm 1.78 \%, 78.12 \pm 11.08 \%$ and $83.48 \pm 1.78 \%$, respectively. The results obtained showed that $M$. scaettae exhibited some resistance where $100 \%$ inhibition was not achieved but considering the doses administered to the culture medium, this fungus remains susceptible to the action of the oil (Photo 1). 


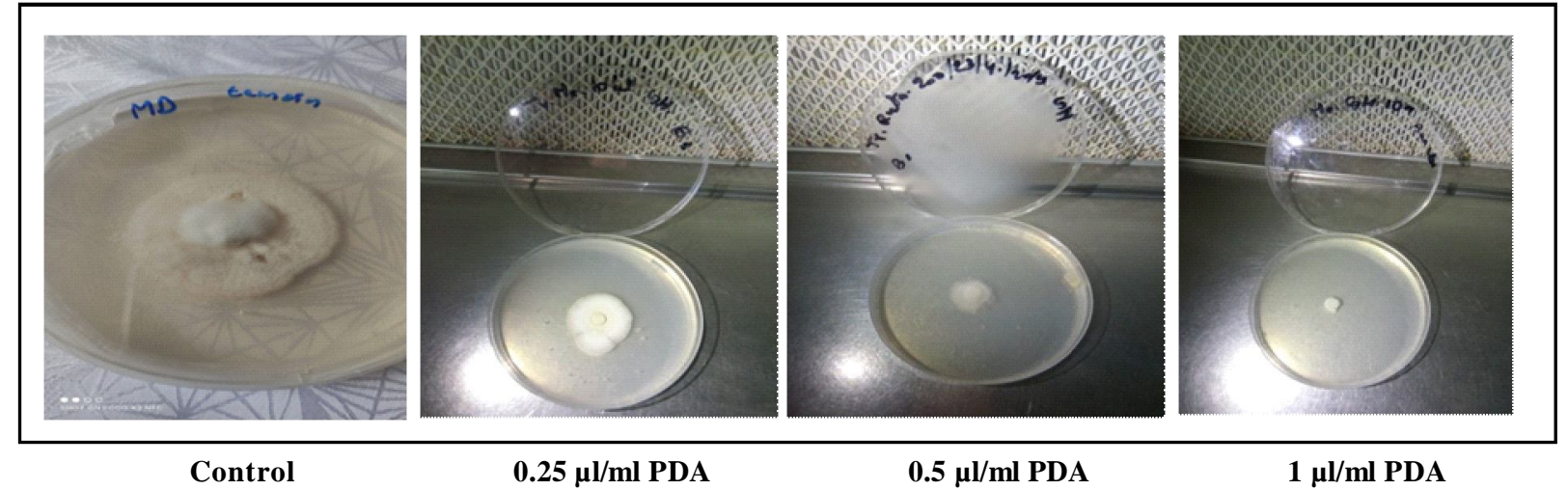

Photo 1: Evolution of mycelial growth according to the different concentrations of essential oil after 7 days of incubation.

\section{Discussion}

The presented results are in agreement with those of Merghache et al. (2009) who showed that the yield of essential oil of $R$. chalepensis collected from Tlemcen (West Algeria) and obtained by hydrodistillation has a yield varies according to the place and period of harvest, respectively of $(0.35-1.28) \%$ and $(0.28-0.84) \%$. While the yield of essential oil is lower than those mentioned in the work of Aouadhi et al. (2013) and Daoudi et al. (2016) which obtained a yield, respectively $0.85 \%$; and $1 \%$. Our study showed that the composition of $R$. chalepensis essential oil is rich in oxygenated monoterpens, especially camphor $(76.57 \%)$. The GC/MS analysis of extracted essential oil of $R$. chalepensis from Beni Mester (West Algeria) revealed 20 compounds representing $64.66-93.99 \%$ of total oil. The major component was 2-undecanone (20.40 - 82.74\%) (Merghache et al., 2009). Indeed, other studies have indicated that the essential oil extracted from $R$. chalepensis from Grarem (East Algeria) is characterized by the abundance of 2-acetoxytetradecane (58.44\%), 2-acetoxytridecane (19.07\%) and 2-tridecanone (6.39\%) (Chibani et al., 2013). However, the works of Ben Bnina et al. (2010), Mejri et al. (2013) and Majdoub et al. (2014) on the same plant originally from different Tunisian regions reported two major constituents: nonan-2-one and undecan-2-one. While the essential oil of $R$. chalepensi from Kef (Tunisia) has several major constituents: menthol $(49.92 \%)$, linalool $(31.1 \%)$ and 2-hexanal (5.2\%) (Aouadhi et al., 2013). Variation in yield and chemical composition of essential oil of $R$. chalepensis may be related to several factors, such as: geographical location, duration and place of drying, temperature, technique and time of extraction, soil type, environmental conditions, diseases caused by exogenous agents, techniques of plant harvesting and extraction, the vegetative plant stage (Daoudi et al., 2016; Bergheul, 2018; Atailia and Djahoudi, 2015).

In this study, the essential oil of $R$. chalepensis characterized by the relatively high content of camphor exhibited an important antifungal power on the tested fungus. These findings suggest that this strong antifungal effect could be related to these major components. Indeed, other reports showed that oxygenated monoterpens as active antimicrobial agents (Lucini et al., 2003; Kordali et al., 2003).

Aouadhi et al. (2013), Ben Bnina et al. (2010) and Bergheul (2018) have demonstrated that the essential oil of $R$. chalepensis from Algeria had significant antifungal activities against Aspergillus niger,
Aspergillus flavus, Alternaria sp, Trichderma sp, Fusarium oxysporum, and Botrytis cinerea and Candida albicans. Indeed, Kordali et al. (2003) demonstrated that oxygenated monoterpens compounds of Artemisia santonicum and Artemisia spicigera essential oils have higher antifungal activities. Wali et al. (2019) have shown that plants can manufacture diverse bioactive metabolites, and those metabolites have the potential for huge pharmacological action. Mathe (2018) has demonstrated that the use of medicinal and aromatic plants in plant protection, especially the versatile forms of utilization of essential oils is promising. The antifungal activity of essential oil can be explained by the synergistic effect between the different essential oil compounds. Lucini et al. (2006) showed that sclerotial differentiation was delayed mainly by camphor, 1.8-cineole, linalool and menthol. Sharma and Tripathi (2006) exhibited that essential oils caused degeneration of fungal hyphae that appeared empty of their cytoplasm content, and loss of rigidity and cell wall integrity.

\section{Conclusion}

In conclusion, This study consisted in evaluating the antifungal capacity of the essential oil of $R$. chalepensis collected from M'chounech (Wilaya of Biskra) against the mycelial growth of $M$. scaettae, fungus responsible for the inflorescence rot of date palm (Phoenix dactylifera L.). The results of this work demonstrated that essential oil could be used as a potential antifungal agent. The chemical analysis of the different compounds of $R$. chalepensis essential oil showed the presence of oxygenated monoterpens. A significant effect was observed against the studied fungus strain. The essential oil tested allowed to limit considerably the development of $M$. scaettae compared to the control. Finally, this study can be exploited for the use of $R$. chalepensis essential oil as a new control strategy against this major constraint of date palm.

\section{Acknowledgements}

We deeply thank Professor Dr. Ramazan ERENLER (Tokat Gaziosmanpasa University-TURKEY) for his help in the realization of the chemical analysis of essential oil of $R$. chalepensis.

\section{Conflict of interest}

The authors declare no conflicts of interest relevant to this article. 


\section{References}

Abdullah, SK.; Asensio, L.; Monfort, E.; Gomez-Vidal, S.; Palma-Guerrero, J.; Salinas, J.; Lopez- Llorca, LV.; Jansson, HB. and Guarro, J. (2005). Occurrence in elx, SE Spain of inflorescence rot disease of date palms caused by Mauginiella scaettae. J. Phytopathology., 153:417-422.

Adams, R.P. (2001). Identification of essential oil components by Gas Chromatography Quadrupole Mass Spectroscopy. Allured Publishing Corp., Carol Stream (III, USA).

Afnor (1986). Huiles essentielles, Recueil de normes françaises. Edition Tech and Doc., Lavoisier, Paris.

Aouadhi, C.; Ghazghazi, H.; Hamrouni, S.; Hasnaoui, B.; and Maaroufi, A. (2013). In vitro antifungal activity of the essential oil and the methanolic extract of Ruta chalepensis. Archs. Inst. Past eur. Tunis., Tom XC: $39-46$.

Atailia, I. and Djahoudi, A. (2015). Chemical composition and antimicrobia activity of geranium essential oil (Pelargonium graveolens L'Hér.) cultivated in Algeria. Phytothérapie, 13:156-162.

Ben Bnina, E.; Hammami, S.; Daamii-remadi, M.; Ben Jannet, H. and Mighri, Z. (2010). Chemical composition and antimicrobial effects of Tunisian Ruta chalepensis L. essential oil. Journal de la société chimique de Tunisie., 12:1-9.

Beniston, N.T. (1984). Fleurs d'Algérie. Entreprise nationale du livre, Alger, pp: 120

Benziouche, SE. and Cheriet, F. (2012). Structure et contraintes de la filière dattes en Algérie. New Medit: 4.

Bergheul, S. (2018). Etude de l'activité antimicrobienne et bioinsecticide de Ruta chalepensis L., R. Angustifolia Pers. Et Haplophyllum tuberculatum (Forsk.) A.Juss.vis-à-vis de quelques bioagresseurs de la culture de tomate (Lycopersicum esculentum Mill). Thèse de Doctorat, Université Abdelhamid Ibn Badis, Mostaghanem, Algérie. pp: 256 .

Bouatrous, Y. (2019). Antibacterial activity of an essential oil and various extracts of the medicinal plant Thymus hirtus sp algeriensis Boiss. and Reut. Ann. Phytomed., 8(2):108-114.

Bouhlali, ET.; Derouich, M.; Meziani, R. and Assarioui, A. (2021). Antifungal potential of phytochemicals against Mauginiella scaettae, the plant pathogen causing inflorescence rot of date palm. Hindawi Scientifica, pp: 8 .

Bounaga, N. and Djerbi, M. (1990). Pathologie du palmier dattier. Ciheam. Options méditerranéennes. les systémes agricoles oasiens., Sér A l: $11-16$

Cahagnier, B. and Richard-Molard, D. (1998). Moisissures des maladies peuhydratés, Les moisissures. Ed. Lavoisier.

Caillet, S. and Lacroix, M. (2007). Les huiles essentielles : Leurs propriétés antimicrobiennes et leurs applications potentielles en alimentaire. INRS-Institut, Armand-Frappier, RESALA Université de Laval, Québec, Canada., pp:1-8

Carpenter, J.B. and Elmer, H.S. (1978). Pests and diseases of the dat palm. U.S. Department of agriculture, Agriculture Handbook., 527:42.
Chabrolin, C. (1930). Les maladies du dattier (Suite et fin). Revue de botanique appliquée et d'agriculture coloniale, 10e année., 108: 661-671.

Chibani, S.; Bouratoua, A.; Kabouche, A.; Laggoune, S.; Semra, Z.; Smati, F. and Kabouche, Z. (2013). Composition and antibacterial activity of the essential oil of Ruta chalepensis subsp. Angustifolia from Algeria. Der. Pharm. Lett., 5(5):252.

Dakhia, N.; Bensalah, MK.; Romani, M.; Djoudi, AM. and Belhamra, M. (2013). État phytosanitaire et diversite varietale du palmier dattier au bas Sahara- Algérie. Journal Algérien des régions Arides., $N^{\circ}$ Spécial.

Daoudi, A.; Harouk, H.; Belaidi, R.; Slimani, I.; Ibijbijen, J. and Nassiri, L. (2016). Valorisation de Ruta montana et Ruta chalepensis: Etude ethnobotanique, Screening phytochimique et pouvoir antibactérien. J. Master. Environ. Sci., 7(3):926-935.

Imad Uddin, MD; Vandana, A.; Kavya, G. and Syed, YH. (2020). Systematic study on protective role of date palm (Phoenix dactylifera L.) on central nervous system disorders. Ann. Phytomed., 9(1):58-65. http:// dx.doi.org/ 10.21276/ap.2020.9.1.7

Ismaily Alaoui, K.; El Hajjaji, F. and Azaroual, M. (2014). Experimental and quantum chemical studies on Corrosion inhibition performance of pyrazolic derivatives for mild steel in hydrochloric acid medium, correlation between electronic structure and inhibition efficiency. Journal Chemistry Pharmacology Researche., 6(7):63-81.

Kordali, S.; Cakir, A.; Zengin, H. and Duru, ME. (2003). Antifungical activities of the leaves of three Pistacia species grown in Turkey. Fitoterapia., 74: $164-167$

Leroux, P. and Credet, A. (1978). Document sur l'étude de l'activité des fongicides. INRA, Versaille, France., pp:12.

Lucini, E.I.; Zunino, M.P.; Lopez, M.L. and Zygadlo, J.A. (2006). Effet des monoterpènes sur la composition lipidique et le développement sclérotique de Sclerotium cepivorum Berk. J. Phytopathol., 154(78):441-446.

Majdoub, O.; Dhen, N.; Souguir, S.; Haouas, D.; Baouandi, M.; Laarif,A. and Chaieb, I. (2014). Chemical composition of Ruta chalepensis essential oils and their insecticidal activity against Tribolium castaneum. Tunisian Journal of Plant Protection, 9(1):83-90.

Mathe, H.A. (2018). Remarks to the recent trends in exploring medicinal plant diversity. Ann. Phytomed., 7(2):1-5.

Mejri, J.; Bouajila, J.; Ben SikAli, S.; Abderrbba, M. and Mejri, M. (2013). Ruta chalepensis L. essential oil: Chemical composition and phytotoxic activity. Journal of Biologically Active Products from Nature., ISSN Print: 2231-1866 Online: 2231-1874 www.jbappn.com

Merghache, S.; Hamza, M and Tabti, B. (2009). Etude physicochimique de l'huile essentielle de Ruta chalepensis L. de Tlemcen, Algérie. Afrique Science. 5(1):67-81

Parveen, B.; Parveen, A.; Parveen, R.; Ahmad, S.; Ahmad, M. and Iqbal, M. (2020). Challenges and opportunities for traditional herbal medicine today with special reference to its status in India. Ann. Phytomed., 9(2):97-112. http://dx.doi.org/10.21276/ap.2020.9.2.8 
Rattan, S.S. and Al-Dboon, A.H. (1980). Notes on fungi associated with datepalm I. Journal Sydowia, 33:246-264

Remmal, A.; Bouchikhi, T.; Rhayour, K.; Ettayebi, M. and Tantaoui-Elaraki, A. (1993). Improved method for the determination of antimicrobial activity of essential oils in agar medium. Journal of Essential Oil Research, 5(2):179-184.
Sharma, N. and Tripathi, A. (2006). Fungitoxicity of the essential oil of citrus sinensis on post-harvest pathogens. World Journal of Microbiology and Biotechnology, 22(6):587-593.

Wali, AF.; Ahmad Hamad, E.; Amer Khazandar, A.; Al-Azzawi, AM.; Sarheed, OA.; Menezes, GA. and Alam, A. (2019). Antimicrobial and in vitro antioxidant activity of Salvia officinalis L. against various re-emergent multi drug resistance microbial pathogens. Ann. Phytomed., 8(2):115-120.

Hadjra Hammia and Yamina Bouatrous (2021). Evaluation of antifungal potential of Ruta chalepensis L. essential oil against Mauginiella scaettae, fungus responsible for the inflorescence rot of date palm (Phoenix dactylifera $\mathbf{L}$.). Ann. Phytomed., 10(2):442-447. http://dx.doi.org/10.21276/ap.2021.10.2.58 